\title{
It's learning development, Jim - but not as we know it: academic literacies in third space
}

\section{Sandra Abegglen}

University of Calgary, Canada

\section{Tom Burns}

London Metropolitan University, United Kingdom

\section{Sandra Sinfield}

London Metropolitan University, United Kingdom

\begin{abstract}
This paper maps our experience of conceptualising and teaching an interdisciplinary firstyear undergraduate 'Higher Education Orientation' module against the seminal paper written by Lea and Street in 1998. We conclude by arguing for Third Spaces within the curriculum and for practices that re-imagine what education is and what the university could be.
\end{abstract}

Keywords: learning development; Third Space; academic literacies; widening participation; higher education.

\section{Introduction}

In United Kingdom higher education students are said to 'read for their degrees'. This indicates that there is very little direct teaching, and if there is, it is often in a traditional lecture format, and that contact-time with academics, those members of the university who teach or research, is limited. Instead the students are expected to be able to organise themselves for independent study and inter-dependent learning. Our students are expected to understand the forms and processes of university teaching and learning; to know how we teach and assess, and what sorts of academic labour - what actual work they have to undertake to get tasks and assessments successfully completed. They are 
also expected to have the motivation and self-discipline to engage actively and proactively with their learning; and to be able to step back from their learning experience to develop critical and analytical approaches, and to engage in reflective practice and writing, to improve on future performance and be employment ready.

The reality is that many students are underprepared for the sort of university teaching and learning environment just described. Increasingly they emerge from a transactional preuniversity system (at least in the United Kingdom) where the emphasis is on teaching to the test' to ensure that students meet performance targets (Jozefkowicz, 2006). Hence, many students struggle to think and act autonomously and powerfully whilst 'selfgoverning' their studies. In our particular institution, London Metropolitan University, this is complicated in that most of our students are classified as 'non-traditional' coming from a 'widening participation' background (London Metropolitan University, 2018); they are often the first in their families to attend university and they work, often full time, alongside having caring responsibilities. This means, our students have little to no time for academic study outside of class time. Further, it tends to mean that our students cannot - or at least do not - engage in the sort of co- or extra-curricular activities that are said to be of most benefit to undergraduates: the clubs and societies that develop students, creating the networks - and feeding the joy - that makes them ready for the world - and for work.

There have been many attempts to develop practice models designed to help nontraditional students succeed at university study. A model particularly embraced in these lean and mean academic times (viz. Giroux, 2014) is the delivery of extra- or co-curricular 'skills' programmes targeted at just those students deemed to be 'at risk', with the aim to bring these students 'up to speed' and 'fix' their deficits. This ignores reiterated warnings not least from the Learning Development (LD) community that widening participation practices should not stigmatise either Learning Development per se nor widening participation students as 'remedial' (viz. ALDinHE, 2019). It also sidesteps the proposition that what facilitates successful widening participation is not 'bolt-on' courses and workshops but the development of creative and inclusive curricula designed to help nontraditional students to succeed and to help all students maximise their potential (Warren, 2002; Wilcox et al., 2005). Targeting resources only at those deemed 'at risk' leaves LD on the sidelines, shouting for equity in this new austerity-driven academia which is anchored almost exclusively in the rhetoric of a reductive employability agenda. 
The purpose of this paper is to map our experience of conceptualising and teaching an interdisciplinary first-year undergraduate 'Higher Education Orientation' module against the seminal paper written by Lea and Street in 1998 that first described this sort of work as a learning taxonomy: skills; socialisation; literacies. We want to discuss our module, Becoming an Educationist, arguing that it is akin to that created by Gutierrez (2008, p.148), 'a collective Third Space, in which students begin to reconceive who they are and what they might be able to accomplish academically and beyond'; and with an emphasis on 'redesigning what counts as teaching and learning of literacy'. We argue this is not 'embedding' LD within the curriculum. Ours is a much more rhizomatic model: one that offers multiple, non-hierarchical entry and exit points (Deleuze and Guattari, 1987) and that embraces uncertainty (Cormier, 2012). It is the collective 'Third Space' (Bhabha, 2004) where by 'being with' you start to 'become' or, as Soja (1996, pp.56-57) said, where

everything comes together . . . subjectivity and objectivity, the abstract and the concrete, the real and the imagined, the knowable and the unimaginable, the repetitive and the differential, structure and agency, mind and body, consciousness and the unconscious, the disciplined and the transdisciplinary, everyday life and unending history.

Thus, our Becoming module welcomed and honoured our diverse non-traditional students for the people they already were as they engaged in the process of becoming the academics that they wanted to become. We therefore argue for holistic and inclusive learning and teaching approaches that enable students to find their own voices in the exclusionary, competitive and often hostile higher education environment.

\section{Becoming: case study module}

In 2013, we developed a first-year undergraduate module that embraced critical pedagogy (Freire, 2007; Giroux, 2007) as it introduced students to their disciplinary subject as well as to (a contested notion of) academia and academic practices. Making use of the ludic and creative, we posed authentic challenges that invited students to actively learn and to interrogate the university as a (co-)constructed learning landscape as they consciously engaged with their own processes of learning. 
Becoming was designed for the first-year undergraduate students of three different courses based in the School of Social Professions. The three courses were aimed at students interested in becoming Educationists in the widest sense: teachers, youth workers, educational instructors, learning consultants, health promoters, community supporters etc. The student body of these courses traditionally consists of over fifty percent non-traditional students (Blagburn and Cloutterbuck, 2011); ours were about 100\% non-traditional. Our students were mature, with work commitments, looking after dependants and attending part-time at least part of the academic year. This means, students on these courses managed, on top of their studies, multiple and often conflicting responsibilities. They also came from a wide range of educational backgrounds, national and international, and hence they struggled to find a 'common ground' for their learning. This presents them with a double bind in that they are either perceived as academically 'deficit' or as lacking commitment to their studies. Similarly, lecturers on those courses find themselves caught between differing professional discourses and contrasting and contradicting demands. Thus, together staff and students tread contested ground, requiring a model of teaching and learning that accommodates the 'flawed self' of both the learner and the teacher: a model that acknowledges and accommodates learning in all its 'supercomplexity' (Barnett and Hallam, 1999) both within academia and the wider world.

Becoming was credit bearing running over the whole of the academic year. This gave the module necessary academic weight and it created time and space not only to explore topics and themes in depth but also to 'be with' each other (Nancy, 2000). This helped students bond and belong; to ease the transition into academia and to reveal that intense engagement with themes and topics creates opportunities for 'rich' learning. Becoming was designed as a rhizomatic (Deleuze and Guattari, 1987) 'de-schooling' (Illich, 1970) space where we embedded emancipatory and creative praxis to help our students become the academics they wanted to be. We utilised 'drawing to learn', 'free writing' and 'blogging' to help students develop thinking and writing habits such that, especially with the blogging, they wrote what they wanted to say - and they wrote often and thus became better at writing (Abegglen et al., 2017). We scaffolded student reading through the use of visual practices (Abegglen et al., 2018) and 'textscrolls' (Middlebrook, 2014; Abegglen at al., 2019), and we asked them to experiment with alternative genres such as songs, dances and videos/films/animations (Burns et al., 2018a, 2018b, 2018c, 2018d, 2018e) 
with the aim to shake up their notions of 'education' whilst making space for them to 'reach their own accommodation with discourses of belonging, identity and power' (Medhurst, 2000, p.31).

Specifically, we decided to develop a module that would welcome all students into the university for the people they already were - as it took them on a developmental journey to become the academics they wanted to be. The module created multiple opportunities for the students to bond and belong - with each other and with the module as a whole. We used role-play and simulation - to get students talking and to validate their thinking. We used drawing and making to learn - with proactive discussion mediated by images, by topic, by objects and by academic texts (Palus and Drath, 2001). The students participated in a range of projects including producing a multimodal exhibition (Abegglen et al., 2016) to showcase results of an early participant observation exercise of what makes learning happen in a university - and what stops learning from happening. Students represented their findings as knitting, poetry, 3D objects, animations, video, collages, comic books and posters. The students blogged their learning - and so wrote to learn - and concomitant formal academic writing flourished as a result (Abegglen et al., 2015). They develop a 'Digital Me' for a further showcase and end of term party; a further opportunity to celebrate their achievements rather than merely 'assess' their learning. They each also engaged in a small qualitative research project on a topic of their own choosing but based around university study. Some of these projects produced innovative findings - such as the first year student who uncovered the benefits of group work because it allowed 'flow' in student directed learning - and another student who discovered that students resisted visual note making because they were frightened of drawing. By the end of the module the students took over the running of the sessions developing interactive learning opportunities for their peers.

Formal and informal feedback, classroom discussions and module evaluations (all carried out throughout the academic year), showed that none of the participating students saw this as a 'deficit fixing' skills module. They saw it as a space to learn and they were capable of learning so much more than they had thought when they entered the university - similar to Gutierrez's (2008) and also Idrus's (2015) students that were 'transformed' by their experiences: 
Thank you very much for taking me to another level of my journey to Become An Educationist, each class was captivating, refreshing and interesting. You are Legends, I am really grateful to have worked with you.

I've spent more time than expected on my portfolio but to say I'm proud is an understatement, you've REALLY inspired my creativity and drive, especially approaching the final hurdle.

Thank you for teaching such an inspirational module. It brought out such creativity within the group and I believe it changed the group dynamics as we had to work with various people whom we generally wouldn't.

Thank you for all your support within the module and the experience was truly invaluable (Anonymised comments taken from 2016 Module Monitoring Log).

Students tend to succeed on Becoming with many receiving $A$ and $B$ grades (in the United Kingdom considered the highest grades), only dropping out, if they do, for personal rather than academic reasons. We argue that the reason for this is that we designed Becoming to be a creative, challenging and engaging module that allowed all members of the nonhomogeneous group labelled 'non-traditional' to develop their self-efficacy and to succeed. Becoming was the hybrid space where they could make sense of themselves as actors and agents in their own learning, of the other modules they were studying, and of the University as a whole.

\section{It's that Lea and Street experience}

Educationists might argue that what we have done in Becoming is simply good curriculum design. Our argument would be that whilst this is true, it is only true because the module was designed to be emancipatory and empowering: something to inspect, laugh at and jump off from (Sinfield et al., 2019). The challenge is to make a case for such a module when the macro-culture within higher education is increasingly focused on the bottom line: NSS scores and League Table positions; student employability and staff salary-reduction targets that need to be reached. This reductionist vision asset-strips creativity from courses and directs or targets resources at those 'in need' rather than learning and 
teaching as a whole (viz. Kalin, 2018). The micro-reality of this is that most widening participation students tend to have experienced some form of educational 'rebuff' and tend to have lower self-efficacy (Bandura, 1982) than middle-class students from a traditional university (Soria and Bultmann, 2014). Thus, for us there is an increased need to develop programmes that better 'hold' those ready to flee, and to foster positive learning experiences and outcomes especially for those who are new to and unsure of (UK) academia. In our module, following Nancy (2000, p. 2), we therefore ensured that our students had enough time and opportunities to 'be with each other' and 'learn together':

There is no meaning if meaning is not shared, and not because there would be an ultimate or first signification that all beings have in common, but because meaning is itself the sharing of Being.

By taking a dialogic rather than a didactic approach, we encouraged the emergence of 'heutagogy' (Hase and Kenyon, 2000): self-directed and self-determined learning. As emancipatory educationists we argue that this should be the ultimate goal of academia: for students to take control of their learning, finding their academic identities in ways that are recognised by the academy, but which they negotiate on their own terms. We were aware that adopting this approach to teaching might be confusing for students used to the lecture-seminar format where the lecturer presents, and represents, the all-knowing teacher (viz. Illich, 1970). However, as our dialogic approach ran through every session, our students adapted and responded well to this new challenge. Moreover we created 'time' - time for students to explore and to experience and experiment with their own learning (viz. Jackson et al., 2006; Johnson, 2010). Time to take risks, to lose a fear of failure and time to 'be with' (Nancy, 2000) and learn from each other; time to create and inhabit their own Community of Practice (Lave and Wenger, 1991).

A Community of Practice (CoP) is a group of people who share a profession or craft and, through the sharing of information and experiences, learn from each other, and so gradually improve their knowledge and/or practice:

Communities of practice are formed by people who engage in a process of collective learning in a shared domain of human endeavor: a tribe learning to survive, a band of artists seeking new forms of expression, a group of engineers 
working on similar problems, a clique of pupils defining their identity in the school, a network of surgeons exploring novel techniques, a gathering of first-time managers helping each other cope. In a nutshell: CoPs are groups of people who share a concern or a passion for something they do and learn how to do it better as they interact regularly (Wenger, cited Wong et al., 2001, p.317).

In other words, CoPs are groups of people who share ideas and insight and help each other solve problems and through that develop a common practice or approach. In academia generally and in Becoming, this meant that students work together on projects, developing ideas and solutions, or plan and create their own learning sessions tailored to their needs and supported by others, who either are more experienced and knowledgeable or who have different experiences and knowledges.

It is a tricky business navigating that which empowers students to operate powerfully within Higher Education, with what facilitates effective teaching (Angelo, 1993) because becoming a learning CoP in this time of 'supercomplexity' (Barnett, 2000) requires the negotiation of identity in a complex dance in complex landscapes of practice that are lanced by multiple meanings and tensions. Creating Becoming as a year-long module with multiple creative challenges gave us, and the students, time for this complexity.

\section{Academic Literacies: A Contested Space}

Lea and Street (1998) discuss in their paper 'Student Writing in Higher Education' the (often contrasting) expectations, interpretations and conceptualisations of learning and teaching. They adduced a taxonomy of approaches to academic writing: describing first a mechanistic study skills model - where the student is deemed to be deficient and in need of remediation via staged 'skills' development; moving through a 'third way' model of academic socialisation - where the student is a learner, but essentially a passive one; and culminating in an academic literacies model which sees the student as having agency in a politicised landscape of power and authority.

In more detail, the study skills approach suggests that there are various discrete skills and strategies that students need to employ to succeed at university study: time management, note making, reading for learning, writing in the correct genre and mode, etc. Lea and 
Street (1998) argue that, in regard to academic writing, this approach conceptualises student writing as technical and instrumental forcing academics and Learning Developers to focus on 'grammar, spelling and punctuation' rather than 'writing to learn'. Whilst we agree with Lea and Street (1998) and reject the idea of atomised skills that students need to master, we do argue that there are moments where students realise that they have not been taught how to study - or learn - successfully and thus where a focus on a particular study approach or strategy might empower them to learn more successfully. For example, when entering university, many will not realise that they need to become active learners, to 'surface' what constitutes academic work, and planning and managing their own academic labour. In our experience, the majority of our students, as with many staff, are unaware of the active learning potential of note making - having been taught instead to passively rely on teaching handouts. Being allowed time and space to explore and rehearse successful note making strategies might improve student agency in their own learning making them less reliant on the good will or the good practice of their tutors. Thus, tackling study strategies directly, and in a supportive and transparent way, need not be experienced as remediation and may enable students to proactively take control of their own learning although the isolated teaching of 'skills' is certainly problematic (Wingate, 2006).

Regardless of their views on skills, most academics acknowledge that disciplines and academic communities have habits and epistemological practices that students need to learn, that they need to model and embrace, in order to become full community members. Lea and Street (1998, viz. also 1997) refer to this as academic socialisation where there is a focus on student orientation to disciplinary learning and interpretation of epistemic learning tasks. Although this approach is much more sensitive to the idea of the student as a learner, the idea is often critiqued for representing students as novitiates, inexperienced learners that need to be moulded into successful adults (and employees) (viz. Kalin, 2018). However, if we take Lave and Wenger's (1991) apprenticeship model of Communities of Practice, it becomes evident that novice students will need to learn how to become academics within their own epistemic communities, and that this need not be a passive and unquestioning indoctrination but, as with the development of successful study strategies as mentioned above, an active, nuanced and embodied process of becoming.

According to Lea and Street (1998), the academic literacies approach, allied to the New Literacies Studies, sees the student as an (active) actor and agent in their own learning, 
subjects capable of operating with awareness and criticality within their epistemic communities. The individual student is no longer seen as potentially deficient - rather questions can be asked of the institution itself and its own systemic ways of hiding or mystifying its power. This contradicts the general assumption and perception that students, especially widening participation students, are lacking the skills and knowledge to succeed in academia and that academic literacy is 'falling' (Brockes, 2003). In this context, Lea and Street (1998) argue that not only current approaches but also current perception in regard to academic literacies need to change. Rather than locating 'problems' within individual students, wider, more empowering institutional approaches to teaching and learning need to be developed, and embedded, that are meaningful within and across the curriculum. Although this argument is plausible, there exist still countless approaches within and across courses, subjects and disciplines - and between students and academic tutors with an underlying assumption that academic literacies are the highest literacies to be achieved. We argue for a more nuanced discussion of and approach to student learning that uses and acknowledges more than one approach. Students need to be provided with a wide range of opportunities that creatively scaffold their learning throughout their studies, and that build on their existing skills and knowledge while creating a sense of purpose and belonging.

Our module was not designed to ensure 'league table outcomes' where power might shift infinitesimally from academics to students, but in reality, it still resides with the higher education institution and its goals (viz. Healey et al., 2018). Rather, in Becoming, we created a collective Third Space by sharing the responsibility for the success of the teaching/learning process - with the students driving 'the action' in partnership with each other and with us: choosing their own qualitative research projects; interpreting their multimodal challenges in their own unique ways; and having creative autonomy in how they developed and delivered the concluding weeks of the module itself. We treated our students not as empty vessels to be filled but as agents harnessing their own particular knowledge and experiences to drive their own learning (and that of others). Thus, our students were gradually given the lead on topics and sessions as the year progressed. We wanted our students to experience a more collaborative, complex, subtle and nuanced version of education and to see and experience themselves as actively learning, and learning as becoming - a realignment of competence and experience, socially defined, personally experienced and collaboratively expressed. 
Looking at the module outcomes and the feedback by our students (and positive comments from the other staff who also taught our students), we argue that all students should be given the sorts of Third Space opportunities that we have described here. Moreover, we argue that it is particularly important for the so-called non-traditional student to have the opportunity to experience Third Space opportunities within their (assessed) modules. These students are the ones who persistently experience educational rejection and refusal, who are labelled as deficient and stereotyped as 'less than'; if Third Space opportunities only happen outwith the curriculum, in the form of Club and Society membership for example, this becomes another way for Higher Education to privilege the traditional and dispossess the non-traditional student. These latter are the students for whom we attempted to create Becoming as a radical, emancipatory and transformative space for action: a space of potentiality.

\section{Whatever next: Whither the transformational educational experiences?}

In austerity-driven higher education there is the danger that university - and all the Learning Development support that is still built into universities - is focused primarily on getting students ready for the market, with ever dwindling resources targeted at widening participation students in ever more stigmatising and diminishing ways. Higher education has itself been marketised and commodified (viz. Giroux, 2007; 2017), thus arguably all the pedagogy, all the learning development, is really about getting everyone into employment and fit for work. Lea and Street (1998) provided a model that criticises this approach and outlined what learning development and support might look like when it goes beyond the teaching of skills and the socialisation of students. Arguably, what is needed is:

a more complex and contested interpretation ... about what constitutes valid knowledge within a particular context, and the relationships of authority that exist around the communication of these assumptions (Lea and Street, 1998, p.170).

This suggests the multiplicity and the diversity in classrooms and lecture halls should be used to explore something as complex as learning and teaching in a more democratic and 
empowering way because it is something that cannot be managed and dealt with in an atomised or mechanistic manner.

In our Becoming module, a first-year undergraduate module, we aimed to promote multidimensional and proactive student learning, designed to engage and develop all of our diverse students. Most importantly, we wanted to value and take into account the whole student, and the subtle range of attributes and practices they bring with them - as well as that which they will need to develop over time to become academic in their own discipline. Underpinning this approach are arguments surrounding critical, emancipatory and empowering pedagogy (Freire, 2007), and an emergent approach to practice that fosters creativity (Jackson et al., 2006) for self-efficacy (Bandura, 1982). We argue that when you set challenges that pique students' curiosity and invite them to critically engage with that which they want to learn - without one particular skills-set in mind - your very fluidity can create more holistic and humanistic (Rogers, 1969) learning and teaching experiences. Built into our model is also the idea of a Community of Practice (Lave and Wenger, 1991) where students have time and space to be with each other and their lecturers (Nancy, 2000). This requires a nuanced literacies approach sustained by continuous and critical reflection (Schön, 1983) upon learning and teaching - and upon the discourses of learning and teaching - from both academics and students:

Becoming has been the most unique and creative module with the Education studies course at the London Metropolitan. Its content has been all-encompassing and has helped me greatly in other modules, yet the real lesson has been the way in which the content has been delivered; the module is democratic and relies heavily on the dialogic. It lets us express ourselves honestly and freely, and asks that we allow others to do the same. Becoming has made me question why we as people rather than just students do or think certain things, and makes us ask if there isn't another way (Extract from a student blog taken from the week that they were asked to reflect on the module overall - viz. The Social Hand Grenade blog).

Our module operated as a collective Third Space for socio-political and critical practice, adopting a critical academic literacies approach and operating in an emergent, oscillating, playful and creative way; capable of engaging and developing the self-efficacy of all our students no matter where they started on their academic journey. 
Based on this experience, if asked 'What next?' or 'Where next?' for the Lea and Street (1998) model and academic literacies per se, we would seek to stand on the shoulders of giants and argue for a paradigm shift in UK higher education teaching and learning. We argue that what widening participation - and all - students deserve and need is a form of the Becoming module at every level of their University study. Students deserve Third Spaces within the curriculum: socio-political spaces that challenge, extend and explore the very nature of knowledge itself; spaces that nurture those more creative and life-enhancing attributes; spaces that continue to value the people our students are as well as the academics they are becoming. We need emancipatory practices within a radical reconfiguration of what education is and what the university could be.

\section{References}

Abegglen, A., Burns, T., Middlebrook, D. and Sinfield, S. (2019) 'Unrolling the text to facilitate learning: the scroll as curriculum disruption', Journal of Learning Development in Higher Education, no.14. Available at:

https://journal.aldinhe.ac.uk/index.php/jldhe/article/view/467 (Accessed 22 September 2019).

Abegglen, S., Burns, T. and Sinfield, S. (2018) 'Drawing as a way of knowing: visual practices as the route to becoming academic', Canadian Journal for Studies in Discourse and Writing/Rédactologie, 28, pp.173-185.

Abegglen, S., Burns, T. and Sinfield, S. (2017) "Really free!': strategic interventions to foster students' academic writing skills', Journal of Educational Innovation, Partnership and Change, 3(1), pp.251-255.

Abegglen, S., Burns, T. and Sinfield, S. (2016) 'The power of freedom: setting up a multimodal exhibition with undergraduate students to foster their learning and help them to achieve', Journal of Peer Learning, 9, pp.1-9.

Abegglen, S., Burns, T. and Sinfield, S. (2015) 'Voices from the margins: narratives of learning development in a digital age', Journal of Educational Innovation, 
Partnership and Change, 1(1) [Online]. Available at:

https://journals.gre.ac.uk/index.php/studentchangeagents/article/view/148 (Accessed: 11 March 2019).

ALDinHE (2019) About: The Association in Learning Development in Higher Education [Online]. Available at: http://www.aldinhe.ac.uk/about/ (Accessed: 4 March 2019).

Angelo, T. A. (1993, April) “Teacher's dozen': fourteen general, research-based principles for improving higher learning in our classrooms', AAHE Bulletin, pp. 3-13.

Barnett, R. (2000) Realizing the university in an age of supercomplexity. Buckingham: Open University Press.

Barnett, R. and Hallam, S. (1999) Teaching for supercomplexity: A pedagogy for higher education, in Mortimore P. (ed.) Understanding pedagogy and its impact on learning. London: Paul Chapman, pp. 137-154.

Bhabha, H. K. (2004) The location of culture. Abingdon: Routledge.

Bandura, A. (1982) 'Self-efficacy mechanism in human agency', American Psychologist, 37(2), pp. 122-147.

Blagburn, P. and Cloutterbuck, S. (2011) 'A multi-disciplinary approach to retention and drop out: a response to institutional concerns', in Access and retention: experiences of non-traditional learners in higher education, University of Lower Silesia, 7-8 April 2011 [Online]. Available at: http://www.dsw.edu.pl/fileadmin/wwwranlhe/files/Blagburn et al.pdf (Accessed: 4 March 2019).

Brockes, E. (2003) 'Taking the mick', The Guardian, 15 January [Online]. Available at: http://www.theguardian.com/politics/2003/jan/15/education.highereducation (Accessed: 5 March 2019).

Burns, T., Sinfield, S. and Abegglen, S. (2018a), 'Regenring academic writing. Case study 1: Collages', Journal of Writing in Creative Practice, 11(2), pp. 181-190. 
Burns, T., Sinfield, S. and Abegglen, S. (2018b) 'Case study 2: Cabinet of curiosity', Journal of Writing in Creative Practice, 11(2), pp. 211-215.

Burns, T., Sinfield, S. and Abegglen, S. (2018c) 'Case study 3: Games and board games', Journal of Writing in Creative Practice, 11(2), pp. 261-266.

Burns, T., Sinfield, S. and Abegglen, S. (2018d) 'Case study 4: Digital storytelling', Journal of Writing in Creative Practice, 11(2), pp. 275-278.

Burns, T., Sinfield, S. \& Abegglen, S. (2018e) 'Case study 5: Multimodal exhibition', Journal of Writing in Creative Practice, 11(2), pp. 297-303.

Cormier, D. (2012) 'Embracing uncertainty: rhizomatic learning' [Online]. Available at: https://www.youtube.com/watch?time continue=95\&v=VJIWyiLyBpQ (Accessed: 4 March 2019).

Deleuze, G. and Guattari, F. (1987) A thousand plateaus: capitalism and schizophrenia. Minneapolis, London: University of Minnesota Press.

Freire, P. (2007) Pedagogy of the oppressed. New York: Continuum.

Giroux, H. A. (2014) Neoliberalism's war on higher education. Chicago: Haymarket Books.

Giroux, H. A. (2007) 'Utopian thinking in dangerous times: critical pedagogy and the project of educated hope', pp. 25-42, in Coté, M. Day, R. and de Peuter, G. (eds.) Utopian pedagogy: radical experiments against neoliberal globalization. Toronto: University of Toronto Press.

Gutierrez, K. D. (2008) ‘Developing a socio-critical literacy in the third space', Reading Research Quarterly, 43(2), pp. 148-164 [Online]. Available at: http://lchc.ucsd.edu/mca/Mail/xmcamail.2014-12.dir/pdftsnR0mXbcJ.pdf (Accessed: 4 March 2019). 
Hase, S. and Kenyon, C. (2000) 'From andragogy to heutagogy', Ulti-BASE In-Site, December [Online]. Available at: http://pandora.nla.gov.au/nphwb/20010220130000/http://ultibase.rmit.edu.au/New/newdec00.html (Accessed: 4 March 2019).

Healey, R. L., Healey, M. and Cliffe, A. (2018) Engaging in radical work: students as partners in academic publishing [Online]. Available at: http://www.efficiencyexchange.ac.uk/12775/engaging-radical-work-studentspartners-academic-publishing/ (Accessed: 5 March 2019).

Idrus, F. (2015) 'Examining classroom transformational spaces using third space theory in developing students' sense of shared identity, Theory and Practice in Language Studies, 5(1), pp.28-37.

Illich, I. (1970) Deschooling society. New York: Harper \& Row.

Jackson, N., Oliver, M., Shaw, M. and Wisdom, J. (eds.) (2006) Developing creativity in higher education: the imaginative curriculum. London: Routledge.

Johnson, S. (2010) Where good ideas come from. London: Penguin.

Jozefkowicz, E. (2006, July) 'Too many teachers 'teaching to the test', The Guardian [Online]. Available at:

https://www.theguardian.com/education/2006/jul/20/schools.uk5 (Accessed: 19 December 2018).

Kalin, N. M. (2018) The neoliberalization of creativity education: democratizing, destructing and decreating. New York: Palgrave Macmillan.

Lave, J. and Wenger, E. (1991) Situated learning: legitimate peripheral participation. Cambridge: Cambridge University Press.

Lea, M. and Street, B. (1998) 'Student writing in higher education: an academic literacies approach', Studies in Higher Education, 23(2), pp. 157-172. 
Lea, M. and Street, B. (1997) Perspectives on academic literacies: an institutional approach. Swindon: Economic and Social Research Council.

London Metropolitan University (2018) About: Our key statistics [Online]. Available at: https://www.londonmet.ac.uk/about/our-university/university-publications/keystatistics/ (Accessed: 11 December 2018).

Medhurst, A. (2000) 'If anywhere: class identification and cultural studies academics', pp. 19-35, in Munt, S. (ed.) Cultural studies and the working class: subject to change. London: Cassell.

Middlebrook, D. (2014) The textmapping project [Online]. Available at: http://www.textmapping.org/ (Accessed: 5 March 2019).

Nancy, J. L. (2000) Being singular plural. Stanford: Stanford University Press.

Palus, C. and Drath, W. H. (2001) 'Putting something in the middle: an approach to dialogue', Reflections, 28(2), pp. 28-39.

Rogers, C. (1969) Freedom to learn: a view of what education might become. Columbus, Ohio: Charles Merrill.

Schön, D. A. (1983) The reflective practitioner: how professionals think in action. New York: Basic Books.

Sinfield, S., Burns, T. and Abegglen, S. (2019) 'Exploration: becoming playful - the power of a ludic module', pp. 23-31, in James, A. and Nerantzi, C. (eds.) The power of play in higher education: creativity in tertiary learning. London: Palgrave Macmillan.

Soja, E. W. (1996) Thirdspace. Malden (Mass.): Blackwell.

Soria, K. and Bultmann, M. (2014) 'Supporting working class students in higher education'. NACADA Journal, 34(2), pp. 51-62 [Online]. Available at: 
https://doi.org/10.12930/NACADA-13-017 (Accessed: 10 October 2018).

Warren, J. R. (2002) 'Reconsidering the relationship between student employment and academic outcomes: a new theory and better data', Youth and Society, 33(3), pp. 366-393.

Wong, K., Kwan, R. and Leung, K. (2001) 'An exploration of using facebook to build a virtual community of practice', pp. 316-324, in Kwan, R., Fong, J., Kwok, L.-F. and Lam, J. (eds.) Hybrid learning: 4th international conference, ICHL 2011, Hong Kong, China, August 2011, Proceedings. London: Springer.

Wilcox, P., Winn, S. and Fyvie-Gauld, M. (2005) "It was nothing to do with the university, it was just the people': the role of social support in the first-year experience of higher education', Studies in Higher Education, 30(6), pp. 707-722.

Wingate, U. (2006) 'Doing away with 'study skills", Teaching in Higher Education, 11(4), pp. 457-469.

\section{Author details}

Sandra Abegglen was formerly Senior Lecturer and Course Leader BA Hons Education Studies at London Metropolitan University, United Kingdom, and is now a researcher based at the University of Calgary, Canada.

Tom Burns is Senior Lecturer in Learning Development in the Centre for Professional and Educational Development (CPED) at London Metropolitan University, United Kingdom. He is co-author of Teaching, Learning and Study Skills: A Guide for Tutors and Essential Study Skills: The Complete Guide to Success at University (4th Edition).

Sandra Sinfield is Senior Lecturer Learning Development in the Centre for Professional and Educational Development (CPED) at London Metropolitan University, United Kingdom, a co-author of Teaching, Learning and Study Skills: A Guide for Tutors and Essential Study Skills: The Complete Guide to Success at University (4th Edition), and a 
Abegglen, Burns

and Sinfield
It's learning development, Jim - but not as we know it: Academic literacies in Third Space

co-founder of ALDinHE. 